Bangladesh J. Zool. 42(2): 183-190, 2014

\title{
INFESTATION OF HELMINTH PARASITES IN GANGETIC LEAFFISH NANDUS NANDUS (HAMILTON, 1822)
}

\author{
Suraiya Parveen and Sabira Sultana* \\ Department of Zoology, Jahangirnagar University, Savar, Dhaka, Bangladesh
}

\begin{abstract}
The present study was conducted to assess the prevalence and intensity of infestation by the helminth parasites in Gangetic Leaffish Nandus nandus (Hamilton, 1822) collected from different fish habitat of Savar Thana of Dhaka district in Bangladesh, during March 2013 to April 2014. A total of 80 fishes were examined and among them 51 were found infected with various helminth parasites with an infection rate of $63.75 \%$ and intensity of infection $4.53 \%$. A total of 231 parasites was recovered from different organs of the fishes, with the highest number from the intestine. Eleven species of helminths were identified, of which three were trematodes (Clinostomum giganticum, C. complanatum, Euclinostomum multicaecum), two were cestodes (Bothriocephalus sp., Senga ophiocephalina), three were acanthocephalans (Pallisentis nandai, P. ophiocephali, Neoechinorhynchus $s p$,) and three were nematodes (Porrocaecum sp., Contracaecum sp., Gnathostoma spinigerum). The prevalence and intensity of parasitic infection were a bit higher in female fish than in male. The parasites were much more abundant in summer $(73.33 \%)$ followed by rainy $(60 \%)$ and winter $(55 \%)$. The larger fishes were heavily infected $(69.23 \%)$ than medium $(64.71 \%)$ and smaller (50\%) fishes.
\end{abstract}

Key words: Helminth parasites, Nandus nandus, prevalence, intensity.

\section{INTRODUCTION}

Parasites are important groups of organisms since it evolved independently in nearly every phylum of animals, from protozoa to arthropods and chordates, as well as in many plant groups. Fish parasitology is a rapidly developing field of aquatic science. This is due to the growing importance of aquaculture, concerns on pollution effects on fish health and a generally increasing interest in environmental biology (Moller and Anders 1986). It is now universally accepted that parasites present a continual and unaccepted threat to the well being of millions of people of the globe specially the people of the tropics and subtropics and to domestic animals in all parts of the world.

The composition of the parasites in fish depends on various factors viz., geographical location of the host, seasons, physicochemical condition of the water, type of soil etc. Dogiel (1961) suggested factors that directly influence parasitic fauna of fish include age, diet and abundance of fish, interdependence of members of parasitic fauna within the fish and the season. Parasitic infestation, more specially helminths infestation is very important because they cause significant damage to their host (Schaperclaus 1986). 
*Author for correspondence: <dina4rm@yahoo.com>.

The Gangetic Leaffishes Nandus nandus are small freshwater fishes of nandidae family mostly found in Southeast Asian countries. It is one of the tasty and delicious fresh water fish and usually available in haors, baors, lakes and ponds. It is very important for its fat but high concentration of protein, lipid, calcium, phosphorus and other useful elements as human nutrients (Chowdhury 2001). However the production of this fish is not in a satisfactory level. The production and growth of this fish are hampered by various ecological and biological factors and also diseases and of the factors, helminth parasites play a major role. The present study was undertaken to assess the prevalence, intensity and distribution of the helminth parasites in relation to sexes, organs and sizes of the host fish N.nandus.

\section{MATERIAL AND METHODS}

A total of 80 host fishes were collected on monthly basis at a regular interval during March, 2013 to February, 2014 from different fish habitat of Savar Thana. After collection, the live fishes were brought to the laboratory of Zoology Department, University of Jahangirnagar for detailed investigation. The fishes were examined to determine their parasite community and to study the prevalence of infestation in relation to sex length groups. On the basis of the total length of $N$. nandus (from the tip of the head to the end of the tail fin) the hosts were divided into three length groups at regular intervals. viz., 5-10. 10.115.1 and 15.2-20.2 $\mathrm{cm}$. The fishes were dissected and removed the digestive tract and urinogenital organs from the body and each organ was put into separate Petridishes. The stomach, intestine, rectum and pyloric part, gall bladder, liver, kidney, muscles and egg sacs were examined by adopting the methods employed by Cable (1977). Trematodes, cestodes, nematodes and acanthocephalans were collected from the host and kept in $70 \%$ ethyl alcohol. Then the parasites were removed from alcohol and mounted temporarily in lactophenol to clear the cuticle of the parasites. To make whole mount of the trematodes, cestodes and nematodes were stained with borax carmine for one and half to two hours and then after dehydrating in alcohol graded series of $35 \%, 50 \%, 70 \%, 85 \%, 95 \%$ and $100 \%$, the parasites were cleaned with xylene and mounted in DPX. Collected parasites were identified by using a compound microscope (Yamaguchi 1958, Soota 1983). The prevalence and mean intensity of the parasites were estimated following the formula suggested by Margolis et al. (1982). 


\section{RESULTS AND DISCUSSION}

During the study period, out of 80 fishes examined $(26$ males and 54 females), only 51 (11males and 40 females) were found to be infected with various helminth parasites. A total of 231 parasites were collected from different infested organs. The prevalence of infestation was $63.75 \%$ (both sexes combined). The intensity of infestation was \pm 4.53 . The prevalence of infestation in male and female hosts was $42.31 \%$ and $74.07 \%$ respectively, (Table 1 ). In the present investigation, it was observed that female hosts were more infected than males. Similar results were also observed by Thomas (1964), Chandra (1985), Khanum and Parveen (1997), Khanum et al. (2008) and Rahman and Saidin (2011). They concluded that this might be due to lower physiological resistance to female fishes rather than the ecological conditions. Whereas, Chowdhury et al. (1983) claimed percentage of infection of parasites in female was higher than in male $N$. nandus. Female fishes were generally found to be more susceptible to the parasites than the males. Similar results also reported by Kennedy and Lie (1974), Wickins and Macfarlane (1971). According to Dobson (1961) females are more susceptible to parasitic infection during breeding season.

Table 1. Prevalence and intensity of helminth parasites in relation to sex of the fish species, Nandus nandus.

\begin{tabular}{lccccc}
\hline $\begin{array}{l}\text { Host } \\
\text { Sex }\end{array}$ & $\begin{array}{c}\text { No. of host } \\
\text { examined }\end{array}$ & $\begin{array}{c}\text { No. of host } \\
\text { infected }\end{array}$ & $\begin{array}{c}\text { Total no. of worm } \\
\text { collected }\end{array}$ & $\begin{array}{c}\text { Prevalence } \\
(\%)\end{array}$ & $\begin{array}{c}\text { Intensity } \\
( \pm)\end{array}$ \\
\hline Male & 26 & 11 & 38 & 42.31 & 3.45 \\
Female & 50 & 40 & 193 & 74.07 & 4.83 \\
Total & 80 & 51 & 231 & 63.75 & 4.53 \\
\hline
\end{tabular}

Table 2. Prevalence and intensity of different groups of helminth parasites in Nandus nandus.

\begin{tabular}{lccccc}
\hline $\begin{array}{l}\text { Helminth } \\
\text { Groups }\end{array}$ & $\begin{array}{c}\text { No. of host } \\
\text { examined }\end{array}$ & $\begin{array}{c}\text { No. of host } \\
\text { infected }\end{array}$ & $\begin{array}{c}\text { Total no. of } \\
\text { worm collected }\end{array}$ & $\begin{array}{c}\text { Prevalence } \\
(\%)\end{array}$ & $\begin{array}{c}\text { Intensity } \\
( \pm)\end{array}$ \\
\hline Trematoda & 80 & 14 & 70 & 17.5 & 5 \\
Cestoda & 80 & 8 & 38 & 10 & 4.75 \\
Acanthocephala & 80 & 9 & 13 & 11.25 & 1.44 \\
Nematoda & 80 & 20 & 110 & 25 & 5.5 \\
\hline
\end{tabular}

The parasites were particularly collected from different parts of the alimentary canal and body cavity. Among the helminth parasitic groups, nematode showed the highest prevalence $(25 \%)$ and intensity $(5.5 \pm)$ and cestode parasite showed lowest prevalence (10\%) and acanthocephala showed lowest

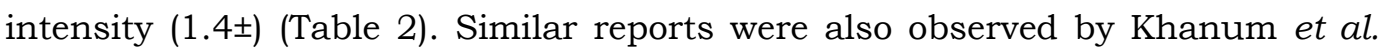
(2011). According to William and Jones (1994) the incidence of nematode parasites was higher than other groups of helminth may be due to the fact that, 
among the different groups of helminths only nematodes undergo both direct and indirect life cycles. They utilized both soil and aquatic environment. Therefore, it may be possible that fishes get infection of nematodes directly through ingestion of contaminated soil, algae and other aquatic animals and plants that constitute the major portion of their food.

Table 3. Prevalence and infestation of helminth parasites in Nandus nandus.

\begin{tabular}{|c|c|c|c|c|c|}
\hline $\begin{array}{l}\text { Names of } \\
\text { Parasites }\end{array}$ & $\begin{array}{l}\text { No. of host } \\
\text { examined }\end{array}$ & $\begin{array}{l}\text { No. of host } \\
\text { infected }\end{array}$ & $\begin{array}{c}\text { Total no. of } \\
\text { worm collected( \% }\end{array}$ & $\begin{array}{l}\text { Prevalence } \\
\text { o) }\end{array}$ & $\begin{array}{c}\text { Intensity } \\
( \pm)\end{array}$ \\
\hline \multicolumn{6}{|l|}{ Trematoda } \\
\hline Clinostomum giganticum & 80 & 07 & 38 & 8.75 & 5.42 \\
\hline Clinostomum complanatum & 80 & 03 & 14 & 3.75 & 4.66 \\
\hline Euclinostomum multicaecum & 80 & 04 & 18 & 05 & 4.5 \\
\hline \multicolumn{6}{|l|}{ Cestoda } \\
\hline Bothriocephalus sp. & 80 & 05 & 24 & 6.25 & 4.8 \\
\hline Senga ophiocephalina. & 80 & 03 & 14 & 3.75 & 4.67 \\
\hline \multicolumn{6}{|l|}{ Acanthocephala } \\
\hline Pallisentis nandai & 80 & 04 & 06 & 05 & 1.5 \\
\hline Pallisentis ophiocephali & 80 & 02 & 02 & 2.5 & 1 \\
\hline Neochinorhynchus sp. & 80 & 03 & 05 & 3.75 & 1.66 \\
\hline \multicolumn{6}{|l|}{ Nematoda } \\
\hline Porrocaecum sp. & 80 & 04 & 13 & 05 & 3.25 \\
\hline Contracaecum sp. & 80 & 11 & 87 & 13.75 & 7.90 \\
\hline Gnathostoma spinigerum & 80 & 05 & 10 & 6.2 & 2 \\
\hline
\end{tabular}

Table 4. Prevalence and intensity of observed parasite in host fishes, Nandus nandus organs.

\begin{tabular}{|c|c|c|c|c|c|c|c|}
\hline $\begin{array}{c}\text { Name of parasites } \\
(\%)\end{array}$ & $\begin{array}{l}\text { Liver } \\
(\%)\end{array}$ & $\begin{array}{c}\text { Body } \\
\text { cavity (\%) }\end{array}$ & $\begin{array}{l}\text { Stomach } \\
(\%)\end{array}$ & $\begin{array}{c}\text { Intestine } \\
(\%)\end{array}$ & $\begin{array}{c}\text { Genital } \\
\text { organ }(\%)\end{array}$ & $\begin{array}{l}\text { Heart } \\
(\%)\end{array}$ & Total \\
\hline $\begin{array}{l}\text { Clinostomum } \\
\text { giganticum }\end{array}$ & 0 & $22(9.52)$ & 0 & $16(6.93)$ & 0 & 0 & 38 \\
\hline $\begin{array}{l}\text { Clinostomum } \\
\text { complanatum }\end{array}$ & 0 & $2(0.87)$ & 0 & $10(4.33)$ & $2(0.87)$ & 0 & 14 \\
\hline $\begin{array}{l}\text { Euclinostomum } \\
\text { multicaecum }\end{array}$ & 0 & $14(6.06)$ & 0 & $4(1.73)$ & 0 & 0 & 18 \\
\hline Bothriocephalina sp. & 0 & 0 & 0 & $24(10.38)$ & 0 & 0 & 24 \\
\hline Senga ophiocephalina & 0 & 0 & 0 & $14(6.06)$ & 0 & 0 & 14 \\
\hline Pallisentis nandai & $4(1.73)$ & 0 & $1(0.43)$ & $1(0.43)$ & 0 & 0 & 6 \\
\hline $\begin{array}{l}\text { Pallisentis } \\
\text { ophiocephali }\end{array}$ & $1(0.43)$ & 0 & 0 & $1(0.43)$ & 0 & 0 & 2 \\
\hline Neochinorhynchus sp. & $1(0.43)$ & 0 & 0 & 0 & $4(1.73)$ & 0 & 5 \\
\hline Porrocaecum sp. & 0 & $10(4.33)$ & $3(1.29)$ & 0 & 0 & 0 & 13 \\
\hline Contracaecum sp. & $3(1.23)$ & $12(5.19)$ & $32(13.85)$ & $38(16.45)$ & 0 & $2(0.87)$ & 87 \\
\hline $\begin{array}{l}\text { Gnathostoma } \\
\text { spinigerum }\end{array}$ & 0 & $3(1.29)$ & $3(1.23)$ & $1(0.43)$ & 0 & $3(1.23)$ & 10 \\
\hline Total (\%) & $9(3.89)$ & $63(27.27)$ & $39(16.88)$ & $109(47.19)$ & $6(2.59)$ & $5(2.16)$ & 231 \\
\hline
\end{tabular}


The prevalence and intensity of infestation of different species of helminth parasites varied greatly from one another. Eleven species of helminth parasites were recovered, of them three species were trematodes Clinostomum giganticum Agarwal, 1960; Clinostomum complanatum Rudolphi, 1814; Euclinostomum multicaecum Tubangui and Masilungan, 1935; two species of cestodes were Bothriocephalus sp., Senga ophiocephalina.Tseng, 1933; three species of acanthocephalans Pallisentis nandai Sarker, 1953, Pallisentis ophiocephali Thapar 1931; Neochinorhynchus sp., 1983; three species of nematodes Porrocaecum sp., Contracaecum sp., Gnathostoma spinigerum Owen, 1836 (Table 3). In the present investigation, it was observed that the Contraceum sp. showed the highest prevalence (13.75\%) and the intensity( $7.90 \pm)$. Bashirullah (1973) first time reported that Pellisentis nandai from $N$. nandus. Chowdhury et al. (1983) also reported two species of nematodes (Contracaeum sp. and ascarididean larvae). On the other hand, Anon (1974), Golder et al. (1987) and Nahida et al. (1994) recorded all these parasitic species in their studied fishes except Clinostomum complanatum. Thus the C. complanatum species is the new record from this research work.

Table 5. Seasonal variations of helminth parasites in Nandus nandus.

\begin{tabular}{lccccc}
\hline Season & $\begin{array}{c}\text { No. of host } \\
\text { Examined }\end{array}$ & $\begin{array}{c}\text { No. of host } \\
\text { infected }\end{array}$ & $\begin{array}{c}\text { Total no. of } \\
\text { worm collected }\end{array}$ & $\begin{array}{c}\text { Prevalence } \\
(\%)\end{array}$ & $\begin{array}{c}\text { Intensity } \\
( \pm)\end{array}$ \\
\hline Summer & 30 & 22 & 151 & 73.33 & 6.86 \\
Rainy & 30 & 18 & 65 & 60 & 3.61 \\
Winter & 20 & 11 & 15 & 55 & 1.36 \\
\hline
\end{tabular}

Organ distribution of helminth parasites were found to maximum in intestine (47.19\%), while it was minimum in heart (2.16\%) (Table.4). Khanum et al. (2011) also observed the maximum helminth infestation from intestine. Present finding is in conformity with Khatun (1995) who concluded that host intestine is the most preferred site for helminth infestation. According to Marcov (1946), fish parasites like other vertebrates, feed either on the digested contents of the host in the alimentary canal or the hosts own tissues. The small intestine seems to be a favorite site for helminth parasites. Sarma (2012) also found the similar results during his study in three murrel host species.

The prevalence and intensity was maximum in summer season $(73.33 \%)$ and minimum in winter season (55\%) (Table 5). Lafferty and Kuris (1999) reported that the factor responsible for this is eutrophication, which often raises parasitism because the association with productivity will increase the abundance of the invertebrate intermediate host's mostly freshwater crustaceans. Another factor may be a drop in water level in the dry season 
exposing the invertebrates to their fish predators. Larue (1951) reported that there are numerous complex factors that influence the parasitic infestation reached peak during the summer season. Lower rate of infestation in winter season may be due to the lack of feeding tendency of the host. Niyogi et al. (1982) suggested that this was due to a temperature dependent rejection process of the hosts.

Table 6. Prevalence and intensity of helminth infestation in different length groups of host fish Nandus nandus.

\begin{tabular}{lccccc}
\hline $\begin{array}{l}\text { Length } \\
\text { groups } \\
\text { cm }\end{array}$ & $\begin{array}{c}\text { No. of host } \\
\text { examined }\end{array}$ & $\begin{array}{c}\text { No. of host } \\
\text { infected }\end{array}$ & $\begin{array}{c}\text { Total no. of } \\
\text { worm collected }\end{array}$ & $\begin{array}{c}\text { Prevalence } \\
(\%)\end{array}$ & $\begin{array}{c}\text { Intensity } \\
( \pm)\end{array}$ \\
\hline $5-10$ & 08 & 04 & 12 & 50 & 03 \\
$10.1-15.1$ & 59 & 38 & 184 & 64.71 & 4.87 \\
$15.2-20.2$ & 13 & 09 & 35 & 69.23 & 3.88 \\
\hline
\end{tabular}

In the present study, the prevalence and intensity varied in relation to the host's body length. The small fishes $(5-10 \mathrm{~cm})$ had less prevalence $(50 \%)$ than the large fishes $(15.2-20.2 \mathrm{~cm})$. The intensity was also highest $(4.87)$ in the medium length group (10.1-15.1) and lower in small length group (15.2-20.2) (Table 6). According to Khanum and Parveen (1997), parasite infestation usually followed a direct relationship with length of Macrognathus acculeatus and Mastacemeleus armatus. They also mentioned that prevalence and intensity were comparatively higher in larger and intermediate size-group of fishes respectively. Noble and Noble (1976) recommended that the relation between the age of host and the kinds and number of its parasites vary considerably according to the circumstances and to the host under consideration. Bashirullah (1973) reported that the degree of parasitism was obviously related to the habit and age of fishes. It is clear from the present study that, helminthes are distributed extensively in the entire gut of edible freshwater fishes. From various geographical regions it has been reported that eating raw or improperly processed fish transfer the parasitic infection to human causing severe laryngitis problem. Since parasite infection cause economic loss to fishery industry as well as zoonotic problem, more and more research works should be carried out on these aspects.

\section{LITERATURE CITED}

ANON.1974. Abstract of fishery research reports 1963-1972. Government of the Peoples Republic of Bangladesh. .

BASHIRULLAH, A.K.M. 1973. A brief survey of the helminth fauna of certain marine and freshwater Fishes of Bangladesh . Bangladesh J. Zool. 1(1): 63-81. 
CABLE R.M. 1977. An Illustrated Laboratory Manual of Parasitology, $5^{\text {th }}$ ed. Burgess Publishing Company, Minneapolis, Minnesota.

CHANDRA, K.J. 1985 . Records of some Trypanorhych pleurocercoids in teleosts of Andhra coast Indian J. Parasitol. 9: 35-137.

CHOWDHURY, M.B.R., HAQUE, A.K.M.A. and ISLAM, M.A.1983. The occurrence of nematode parasites in nandid fish. Bangladesh J. Agricult. Sci. 10: 37-42.

CHOWDHURY, M.B.R., 2001. The occurrence of nematode parasites in nandid fish. Bangladesh J. Agricult. Sci.10: 37-42.

DOBSON, C. 1961. Certain aspects of the host parasites relation of nematode Spirudaedubius (Buylis), I. resistance of male and female mice to experiment infection. Parasitol. 51: 173-179.

DOGIEL, V.A. 1961. Ecology of parasites of freshwater fishes. In: Parasitology of fish (VA Dogiel, GK Petrushevski and Yu 1 Polynski, eds.). London. Oliver and Boyd. 120-146.

GOLDER, M.I., CHANDRA, K.J., and RAHMAN, A.K.A. 1987. Helminth parasitism in Nandus nandus (Hamilton). Bangladesh J. Fish. 10(2): 11-22.

KENNEDY, C.R and LIE, S.F. 1974. The distribution and pathogenicity of larvae of Eustrongyllids (Nematode) in brown trout, Salmo trutta L. in Feraworthy Reservior. Devon. J . Fish. Biol. 8: 193-302.

KHANUM, H and PARVEEN, S. 1997. Organal distribution and seasonal prevalence of endoparasites in Macrognathus aculeatus Smith and Macrognathus armatus Day. Bangladesh J. Zool. 25(1) 15-21.

KHANUM, H., BUGUM, N. and BEGUM, A. 2008. Infestation of helminth parasites in the Panna micrdon (Bleeker, 1849) Dhaka Univ. J . Biol. Sci. 17(1): 51-57 .

KHANUM, H., BUGUM, N. and BEGUM, A. 2011. Seasonal Prevalence, Intensity and Organal distributionof Helminth Parasites in Macrognathus aculeatus. Dhaka Univ. J. Biol. Sci. 20(2): 117-122.

KHATUN, F.A.1995. Metazoan Parasites of some freshwater fishes of Comilla, Bangladesh. M.Sc. thesis. Dept. of Zool. Chittagong University. 162

LAFFERTY, K.D. and KURIS, A.M. 1999. How environmental stress affects the impacts of parasites. Limnology and Oceanography, 44:925-931.

LARUE, G.R 1951. Host parasite relations among the digenetic trematodes. J. Parasitol. 37: 333342.

LANDBERGE, J.H., BLAKESLY, B.A., REESE,R.O., MCRAE, G. and FORSTCHEN, P.R., Parasite of fish as indicators of environmental stress. Env. Monit.Assess. 51: 211-232.

MARGOlis, 1., ESCH, G. W., HOLME, J. C., KWIS, A. M. and SCHAD, G. A. 1982. The use of ecological terms in parasitology (Report of an adhoc committee of the American Society of Parasitology). J Parasitology, 68(1): 131 - 133.

MARKOV, G.S. 1946. Modes of feeding parasites Priroda, XII, ( Cited form Dogiel, VW 1961). General Parasitology, Leningrad Univ. Press (English translation, Z . Kabata ) Oliver and Boyd, Edinburg .

MOLLER, H and ANDERS, K. 1986. Diseases and Parasites of Marine fishes. Kiel.: Moller:365 PP.

NAHIDA, T.K., KHATUN, A. and D' SILVA, D. 1994. The histopathology of infested organs in Nandus nandus (Hamilton). Proc. Ninth Zool. Conf. Bangladesh. pp. 51-54.

NOBLE, E.R. and NOBLE, G.A 1976. The Biology of Animal Parasites, 4th edn., Philadelphia, La and Febiger, pp.556.

NIYOGI, A., GUPTA, A.K. and AGRAWAL, S.M. 1982. Population dynamics of caryophyllids Parasitizing Clarias batrachus at Raipur. Geibios New Reports:1: 81-93. 
RAHMAN, W.A. and SAIDIN, H. 2011. Relationship between sex and parasite intensity in four freshwater fish species from Tasik Merah, Perak, Penisular Malaysia. World.J. Zoology, 6(4): 370-374.

SARMA, K. 2012. Seasonal incidence of Helminth Parasite of three selected Murrel Fish Species of Assam, A thesis submitted to Gouhati University for the award of the degree Doctor of Philosophy in Zoology in Faculty of Science, 136-137.

SCHAPERCLAUS, W. 1986. Fish Diseases, Oxanian Press Pvt. Ltd., New Delhi, pp. 594.

SOOTA T.D. 1983. Studies on Nematode parasites of Indian vertebrates, I. Fishes. Rec., Zool. Survey of India, occ. paper no. (544) 352.

THOMAS, J.D. 1964. A comparison between the helminth burden of male and female brown trout Salmo trutta L. from a natural population in the river Teify. West Wales Parasitology 4: 263-272.

WICKINS, J.F and MACFARLANE, I.S. 1971. Some difference of parasitic fauna of three samples of Plaice ( Pleuronectes platessa L.) from the southern North Sea . J . Fish. Biol. 5: 9-19.

WILliamS, H. and JONES , A.1994. Parasitic Worms of Fish, Taylor and Francis Publishers Ltd., pp 443.

WORLD HEALTH ORGANIZATION. 1995. Control of food borne trematode infections, Geneva: WHO, 1-107.

YAMAGUCHI, 1958. The digenetic trematodes of vertebrates, Systema Helminthum. Vol I. Part I and II. New York, Interscience Publishers.

(Manuscript received on 29 October, 2014; revised on 26 November, 2014) 